\title{
Relationship between serum osteopontin levels and the severity of COVID-19 infection
}

\author{
Ceyhun Varım - Taner Demirci (D) - Hasret Cengiz (D) - Illhan Hacıbekiroğlu (D) Fatima Betul Tuncer (ID) \\ Erdem Çokluk (D) - Hande Toptan (D) - Oguz Karabay (D) · Ilhan Yıldırım (iD
}

Received: 5 October 2020 / Accepted: 26 November 2020 / Published online: 28 December 2020

(C) Springer-Verlag GmbH Austria, part of Springer Nature 2020

\begin{abstract}
Summary
Background Coronavirus disease 2019 (COVID-19) is an acute inflammatory respiratory disease. Osteopontin $(\mathrm{OPN})$ is a glycoprotein expressed in various cell types, such as bone, immune, smooth muscle, epithelial and endothelial cells. It also acts as a regulator of immune response. The aim of the present study was to reveal the place of serum osteopontin levels in predicting severity among patients with COVID-19.

Methods This study included 84 patients, 43 female and 45 male. Patients were divided into 2 groups, group 1 non-severe group ( $n$ : 48), group 2 severe ( $n$ : 40). Demographic data, neutrophil, lymphocyte, platelet, white blood cell counts, albumin, procalcitonin, C-reactive protein (CRP) and OPN levels were recorded. The OPN levels and these inflammatory parameters of the two groups were compared.
\end{abstract}

\footnotetext{
Associate Professor C. Varım $(\bowtie) \cdot$ İ. Ylldırım

Department of Internal Medicine, Sakarya University

Medicine Faculty, Sakarya, Turkey

ceyhunvarim@yahoo.com

İ. Yildırım

driyldrm@gmail.com

Assistant Professor T. Demirci

Department of Internal Medicine, Division of

Endocrinology, Sakarya University Medicine Faculty,

Sakarya, Turkey

tnrdemirci@gmail.com

\section{H. Cengiz}

Department of Endocrinology, Sakarya University Medicine Faculty, Sakarya, Turkey

drhasretc@gmail.com
}

Associate Professor İ. Hacıbekiroğlu

Department of Medical Oncology, Sakarya University

Medicine Faculty, Sakarya, Turkey

ilhanhbo@hotmail.com
Results There were no significant differences in terms of gender (female/male $25 / 23$ vs. 18/22) and platelet count $(178 \mathrm{~K} / \mu \mathrm{L}$ vs. $191 \mathrm{~K} / \mu \mathrm{L})$ between the groups ( $p>0.05)$. Ages $(57.7 \pm 17.0$ years vs. $71.4 \pm 12.8$ years), procalcitonin (0.07 vs. $0.24 \mathrm{ng} / \mathrm{mL})$, CRP (17 vs $158 \mathrm{mg} / \mathrm{l})$, neutrophil count $(3.7$ vs $5.64 \mathrm{~K} / \mu \mathrm{L})$, WBC counts $(5.38$ vs $7.85 \mathrm{~K} / \mu \mathrm{L})$ and number of deaths ( 0 vs 26) $(p<0.001)$. The OPN levels $(98.5$ vs $13.75 \mathrm{ng} / \mathrm{mL}$, $p=0.002$ ) were found to be statistically higher, in group 2 than group 1 .

Conclusion The present study showed that OPN can be used to predict the severity in patients with COVID19.

Keywords Osteopontin · COVID-19 - Severity · Pandemic $\cdot$ Inflammation

\footnotetext{
E. Çokluk

Department of Medical Biochemistry, Sakarya University Medicine Faculty, Sakarya, Turkey erdemcokluk205@hotmail.com

F. B. Tuncer $\cdot$ H. Toptan

Department of Clinical Microbiology, Sakarya University Medicine Faculty, Sakarya, Turkey

F. B. Tuncer

fbtuncer07@gmail.com

H. Toptan

hande_cakar@hotmail.com

Professor O. Karabay

Department of İnfection Diseases and Clinical Microbiology, Sakarya University Medicine Faculty, Sakarya, Turkey okarabay@sakarya.edu.tr
} 


\section{Introduction}

Coronavirus disease 2019 (COVID-19), as named by the World Health Organization, is caused by severe acute respiratory syndrome coronavirus 2 (SARS-CoV2 ). This novel virus is a member of coronavirus family, which includes SARS-CoV and Middle East respiratory syndrome (MERS) CoV. Coronaviruses (CoV) are zoonotic single chain enveloped RNA viruses with positive polarity. They can cause infections in humans and animals, including mammals such as birds, camels, cats and bats. As a result of detailed research, it has been determined that SARS-CoV-2 is transmitted from musk cats, while MERS-CoV is transmitted from single humped camels to humans. The ultimate source of the SARS-CoV-2 virus has yet to become clear; however, it is likely that the source was wild animals illegally sold in the Huanan Chinese seafood wholesale market [1-4].

Osteopontin (OPN) is a glycoprotein released by many tissues and cell types. OPN was first described by Hynes et al. in 1979 [5]. Osteopontin is also known as early $\mathrm{T}$ lymphocyte activation-1 [6]. It plays a role as a chemotactic factor for many cells and has also been shown to play a role in migration of neutrophils and mast cells, as well as a chemotactic factor for macrophages $[7,8]$. Osteopontin suppresses interleukin 10 (IL-10) production in T-helper 2 (TH2) cells, increasing the inflammatory response of $\mathrm{TH} 1$ cells. Osteopontin also increases the immunoglobulin production from B cells and B cell proliferation [9].

In this study, we aimed to show the relationship between osteopontin levels and COVID-19 infection; and also reveal the role of osteopontin in predicting severity in patients with COVID-19.

\section{Material and methods}

A total of 84 patients (43 women, 45 men) hospitalized in the clinic of internal medicine at the Sakarya University Medical Faculty between 1 April 2020 and 31 May 2020 and who were tested for COVID-19 with real-time reverse transcription polymerase chain reaction (rRT-PCR) were enrolled in the study. Nasal and pharyngeal swabs were obtained from all patients. Isolated patient samples that were obtained with viral nucleic acid test (VNAT) viral transport, brought to the molecular virology laboratory and examined using Biospedy (Bioeksen Ar Ge Teknolojileri Ltd. Şti. Sarıyer, İstanbul, Turkey) rRT-PCR kits provided by the Ministry of Health of Turkey. The patients whose rRTPCR results were positive were regarded as COVID-19 $(+)$.

Demographic and clinical hospital records of all patients above 18 years were analyzed retrospectively. Blood samples were taken from all groups in tubes containing ethylenediamine tetraacetic acid (EDTA) and non-EDTA. Blood samples taken in EDTA tubes for hematological tests were studied on the same day.
Blood samples in non-EDTA tubes were centrifuged at $+4{ }^{\circ} \mathrm{C} 3000 \mathrm{rpm}$ for $10 \mathrm{~min}$. Sera were immediately separated from the cells after centrifugation. Serum samples for the measurement of human osteopontin were stored at $-80^{\circ} \mathrm{C}$ until use. Serum osteopontin levels were measured using the sandwich ELISA method (Elabsience, Bioassay Technology Laboratory, Shangai, China). The reference range for osteopontin was taken into consideration at between 0.3 and $90 \mathrm{ng} / \mathrm{mL}$. In a precision study conducted by the manufacturer, the within-run and between-run correction value of the kits were given as $<10 \%$.

The patients were divided into two groups based on the severity of the disease. Hence, there was a noncritically ill group (consisting of 48 patients) and a critically ill group (consisting of 40 patients). The critical illness class included patients with respiratory failure (respiratory rate $\geq 30 / \mathrm{min}$, arterial oxygen partial pressure/fractional inspired oxygen critical $\left[\mathrm{PaO}_{2} / \mathrm{FiO}_{2}\right]<300$ (arterial oxygen partial pressure [Pao2 in $\mathrm{mmHg}$ ] to fractional inspired oxygen [FiO2]), $\mathrm{SpO} 2<90 \%$ or $\mathrm{PaO} 2<70 \mathrm{~mm} \mathrm{Hg}$ despite $5 \mathrm{~L} / \mathrm{min}$ oxygen therapy), shock (systolic blood pressure $<90$ and $40 \mathrm{~mm} \mathrm{Hg}$ from usual SBP and mean arterial pressure $<65 \mathrm{~mm} \mathrm{Hg}$, tachycardia $>100 / \mathrm{min}$ ) or multiorgan dysfunction (acute kidney damage, acute liver function test disorder, development of acute organ dysfunction such as confusion, acute bleeding diathesis).

This study was approved by the local ethics committee and performed in accordance with the Helsinki Declaration (31.08.2020-71522473/050.01.04/468).

\section{Statistical analysis}

Data analysis was performed by using SPSS-22 for Windows (Statistical Package for Social Science, SPSS, Chicago, IL, USA). The variables were investigated using visual (histograms, probability plot) and analytical methods (Kolmogorov-Smirnov/Shapiro-Wilk tests) to determine whether or not they were normally distributed. We performed analyses to describe and summarize the distributions of the variables. The continuous variables were expressed in terms of mean and standard deviation or as median and interquartile range, depending on the normality of the distribution. Differences between qualitative/categorical variables, such as gender distribution between groups, were compared with the $\chi^{2}$-test since the values observed in the cells provided assumptions. The Mann-Whitney test was used to compare the variables that were not normally distributed. Additionally, Student's t-test was used to compare the variables with normal distribution. While investigating the associations between non-normally distributed variables, the correlation coefficients and their significance were calculated using Spearman's test. The statistically significant two tailed $p$-value was set at $<0.05$. 


\section{Results}

A total of 84 patients were included in this prospective study. The groups (group 1 non-critically ill patients, group 2 critically ill patients) were determined to be homogeneous in terms of gender. There were no significant gender differences between the two groups. Average age was $57.7 \pm 17.0$ years in group 1 and $71.4 \pm 12.8$ years in group 2 at $p<0.001$ (Table 1).

The white blood cell (WBC), platelet, neutrophil counts, albumin, D-dimer, ferritin, and C-reactive protein (CRP) and osteopontin levels of group 1 and group 2 are shown in Table 2.

The WBC counts were $5.38 \mathrm{~K} / \mu \mathrm{L}(4.83-6.85)$ in group 1 and $7.8510^{3} / \mathrm{mm}^{3}(5.97-10.7)$ in group 2 at $p<0.001$. Platelet counts were $178 \mathrm{~K} / \mu \mathrm{L}(150-201)$ in group 1 and $191 \mathrm{~K} / \mu \mathrm{L}(146-279)$ in group 2 , at $p 0.289$. Neutrophil counts were $3.7 \mathrm{~K} / \mu \mathrm{L}(2.85-4.79)$ in group 1 and $5.64 \mathrm{~K} / \mu \mathrm{L}(4.65-8.73)$ in group 2 , at $p<0.001$. Albumin levels were $33.10 \mathrm{~g} / \mathrm{L}(29.85-37.05)$ in group 1 and $29.90 \mathrm{~g} / \mathrm{L}(26.60-33.00)$ in group 2 , at $p<0.001$. D-dimer levels were $508.5 \mathrm{ng} / \mathrm{mL}(225.5-790.3)$ in group 1 and $1170 \mathrm{ng} / \mathrm{mL}(757.5-2402.5)$ in group 2, at $p<0.001$. Ferritin levels were $232.0 \mathrm{ng} / \mathrm{mL}(94.75-$ $622.75)$ in group 1 and $479.5 \mathrm{ng} / \mathrm{mL}(252.5-1357.8)$

Table 1 Demographic characteristics of non-critically ill and critically ill patients

\begin{tabular}{|llll|}
\hline Parameters & $\begin{array}{l}\text { Non-critically ill } \\
\text { patients }\end{array}$ & $\begin{array}{l}\text { Critically ill } \\
\text { patients }\end{array}$ & $P$ values \\
\hline Patients $(n)$ & 48 & 40 & - \\
\hline Male/female $(n)$ & $25 / 23$ & $18 / 22$ & 0.508 \\
\hline Age (years) & $57.7 \pm 17.0$ & $71.4 \pm 12.8$ & $>0.001$ \\
\hline
\end{tabular}

Table 2 Comparison of clinical and laboratory results of non-critically ill and critically ill patients

\begin{tabular}{|c|c|c|c|}
\hline Parameters & $\begin{array}{l}\text { Non-critically ill } \\
\text { patients } \\
(n: 48)\end{array}$ & $\begin{array}{l}\text { Critically ill patients } \\
(n: 40)\end{array}$ & $P$ values \\
\hline$D$-dimer (ng/mL) & $\begin{array}{l}508.5 \\
(225.5-790.3)\end{array}$ & $\begin{array}{l}1170 \\
(757.5-2402.5)\end{array}$ & $<0.001$ \\
\hline Ferritin (ng/mL) & $\begin{array}{l}232 \\
(94.75-622.75)\end{array}$ & $\begin{array}{l}479.5 \\
(252.5-1357.8)\end{array}$ & 0.006 \\
\hline$C R P(\mathrm{mg} / \mathrm{L})$ & $\begin{array}{l}17.0 \\
(5.25-45.5)\end{array}$ & $\begin{array}{l}158.0 \\
(132-182.5)\end{array}$ & $<0.001$ \\
\hline$W B C(\mathrm{~K} / \mu \mathrm{L})$ & $\begin{array}{l}5.38 \\
(4.83-6.85)\end{array}$ & $\begin{array}{l}7.85 \\
(5.97-10.7)\end{array}$ & $<0.001$ \\
\hline$P L T(\mathrm{~K} / \mu \mathrm{L})$ & $\begin{array}{l}178 \\
(150-201)\end{array}$ & $\begin{array}{l}191 \\
(146-279)\end{array}$ & 0.289 \\
\hline$N E U(\mathrm{~K} / \mu \mathrm{L})$ & $\begin{array}{l}3.70 \\
(2.85-4.79)\end{array}$ & $\begin{array}{l}5.64 \\
(4.65-8.73)\end{array}$ & $<0.001$ \\
\hline$L Y M(\mathrm{~K} / \mu \mathrm{L})$ & $\begin{array}{l}1.3 \\
(0.9-1.8)\end{array}$ & $\begin{array}{l}0.79 \\
(0.48-1.05)\end{array}$ & $<0.001$ \\
\hline Albumin $(\mathrm{g} / \mathrm{L})$ & $\begin{array}{l}33.10 \\
(29.85-37.05)\end{array}$ & $\begin{array}{l}29.90 \\
(26.60-33.00)\end{array}$ & $<0.001$ \\
\hline $\begin{array}{l}\text { Osteopontin } \\
\text { (ng/mL) }\end{array}$ & $\begin{array}{l}9.85 \\
(8.32-19.23)\end{array}$ & $\begin{array}{l}13.75 \\
(11.30-17.07)\end{array}$ & 0.002 \\
\hline Death $n(\%)$ & 0 & $33(55)$ & $<0.001$ \\
\hline
\end{tabular}

Table 3 Correlation analysis between serum inflammatory markers and osteopontin

\begin{tabular}{|c|c|c|}
\hline & \multicolumn{2}{|c|}{ Spearman's correlations (osteopontin) } \\
\hline & r value & $p$ value \\
\hline C-reactive protein (CRP) & 0.326 & 0.051 \\
\hline$D$-dimer & 0.302 & 0.016 \\
\hline Procalcitonin & 0.359 & 0.008 \\
\hline White blood cell count & 0.400 & 0.054 \\
\hline
\end{tabular}

in group 2, at $p<0.006$. CRP levels were $17.0 \mathrm{mg} / \mathrm{L}$ (5.25-45.5) in group 1 and $158.0 \mathrm{mg} / \mathrm{L}$ (132-182.5) in group 2, at $p<0.001$. Osteopontin levels were $9.85 \mathrm{ng} / \mathrm{mL}(8.32-19.23)$ in group 1 and $13.75 \mathrm{ng} / \mathrm{mL}$ (11.30-17.07) in group 2 at $p:<0.002$. The number of deaths were 0 in group 1 and 33 in group 2 , at $p$ $<0.001$ (Fig. 1; Table 2).

We performed a correlation analysis between serum inflammatory markers and osteopontin, finding a positive correlation between serum osteopontin levels and CRP, procalcitonin, WBC, and D-dimer (Table 3).

\section{Discussion}

We found higher WBC, neutrophil, D-dimer, CRP, ferritin and osteopontin levels and lower lymphocyte and albumin levels in the critically ill patients than the non-critically ill patients in our study. Higher WBC, neutrophil, D-dimer, CRP, and ferritin levels and lower lymphocyte and albumin levels are associated with poor prognosis.

Neutrophils and lymphocytes are important components of the immune system. Neutrophils are cells that release chemokines and cytokines. These cytokines and chemokines stimulate angiogenesis, cytogenesis, antiviral defence, and help regulation of immune response [10]. In severe viral infections, the number of neutrophils in peripheral blood increases significantly; increased neutrophil counts induce cytokine-chemokine storms and ultimately lead to lung injury and acute respiratory distress syndrome [11].

Osteopontin is a glycophosphoprotein first found in bone tissue. Later, it was found that osteopontin was released from many tissues, such as the brain, mammary glands, kidneys and smooth muscle. Additionally, immune cells such as macrophages, dendritic cells (DC), neutrophils, eosinophils, natural killer (NK) cells, NKT cells, and T and B lymphocytes express osteopontin [6]. It has been shown to play a role in migration of neutrophils and mast cells and as a chemotactic factor for macrophages [7, 8]. Osteopontin also increases immunoglobulin production from B cells and B cell proliferation [12].

The relationship between COVID-19 infection and cellular and humoral immune systems was studied. COVID 19 infection stimulates the T cell-mediated immune system like other viral infections [13]. As the disease progresses, both $\mathrm{CD}^{+}$and $\mathrm{CD}^{+} \mathrm{T}$ cell counts 
Fig. 1 Comparison of osteopontin levels (median) between of non-critically ill and critically ill groups according to the clinical severity of the disease

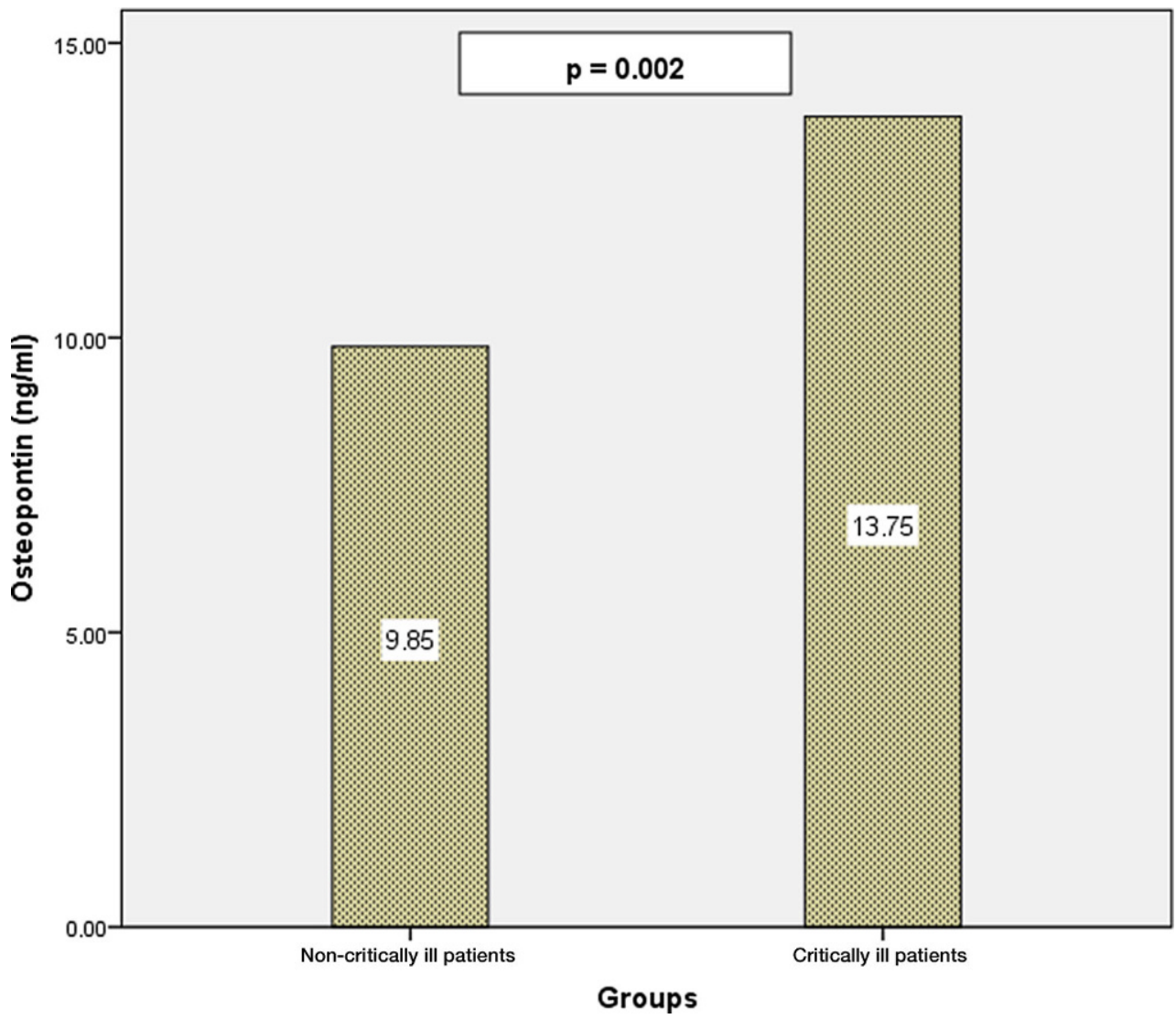

decrease [14]. In one study it was also showed that activated CD4+ and CD8+ $\mathrm{T}$ cells are present in the blood before the relief of symptoms [15].

Immunoglobulin $\mathrm{M}$ and $\mathrm{G}$ type antibodies specific to COVID-19 form the basis of the disease diagnosis [16]. High levels of IgG antibodies were found to be associated with the severity of the disease. As the serum antibody titer increases, the severity of the disease increases. In particular, the IgM antibody titer is an independent risk factor for disease severity [17]. These findings indicate that COVID-19 infection is associated with B cell activation and proliferation [18].

We found higher osteopontin levels in critically ill patients than non-critically ill patients. These high levels of osteopontin are associated with more activation of macrophages, dendritic cells (DCs), neutrophils, eosinophils, NK cells and T and B lymphocytes in critical patients. Many studies have suggested that osteopontin is a valuable marker of autoimmune and inflammatory disorders, such as inflammatory bowel diseases, systemic lupus erythematosus, asthma, and rheumatoid arthritis [19-21]. Our findings are consistent with the literature.

One of the limitations of our study relates to the considerable age differences between the patients of the critically ill vs. the non-critically ill group (71 years vs. 58 years, $p<0.001)$. Chang et al. described a positive correlation between serum osteopontin levels and age. Thus, the possibility exists that the higher osteo- pontin levels of the critically ill patients are merely a reflection of the higher age of this group [22].

In conclusion, osteopontin is a valuable marker of COVID-19 infection and can be used for predicting the severity of this infection. Larger scale randomized studies are needed to clarify the relationship between COVID-19 infection and osteopontin.

\section{Compliance with ethical guidelines}

Conflict of interest C. Varım, T. Demirci, H. Cengiz, İ. Hacıbekiroğlu, F.B. Tuncer, E. Çokluk, H. Toptan, O. Karabay, and İ. Ylldırım declare that they have no competing interests.

Ethical standards Informed consent was obtained from all patients. Data were obtained for scientific purposes. The study protocol was approved by the ethics committee of Sakarya University Medical Faculty and was conducted in accordance with the principles of the Declaration of Helsinki (31.08.202071522473/050.01.04/468).

\section{References}

1. Gorbalenya AE, Baker SC, Baric RS, et al. Severe acute respiratory syndrome-related coronavirus: the species and its viruses-a statement of the Coronavirus Study Group. bioRxiv. 2020.

2. Chen Y, Liu Q, Guo D. Emerging coronaviruses: genome structure, replication, and pathogenesis. J Med Virol. 2020;92(4):418-23. https://doi.org/10.1002/jmv.25681.

3. Stancioiu F, Papadakis GZ, Kteniadakis S, Izotov BN, Coleman MD, Spandidos DA, et al. A dissection of SARS- 
CoV2 with clinical implications (Review). Int J Mol Med. 2020;46(2):489-508. https://doi.org/10.3892/ijmm.2020. 4636.

4. Wu JT, Leung K, Leung GM. Nowcasting and forecasting the potential domestic and international spread of the 2019nCoV outbreak originating in Wuhan, China: a modelling study. Lancet. 2020;395:689-97. https://doi.org/10.1016/ S0140-6736(20)30260-9.

5. Fisher LW, Whitson SW, Avioli LV, Termine JD. Matrix sialoprotein of developing bone. J Biol Chem. 1983;258(20):12723-7.

6. Inoue M, Shinohara ML. Intracellular osteopontin (iOPN) and immunity. Immunol Res. 2011;49(1-3):160-72. https://doi.org/10.1007/s12026-010-8179-5.

7. Koh A, da Silva AP, Bansal AK, Bansal M, Sun C, Lee H, et al. Role of osteopontin in neutrophil function. Immunology. 2007;122(4):466-75. https://doi.org/10.1111/j.1365-2567. 2007.02682.x.

8. Nagasaka A, Matsue H, Matsushima H, Aoki R, Nakamura Y, Kambe N, et al. Osteopontin is produced by mast cells and affects IgE-mediated degranulation and migration of mast cells. Eur J Immunol. 2008;38(2):489-99. https://doi.org/ 10.1002/eji.200737057.

9. Burdo TH, Wood MR, Fox HS. Osteopontin prevents monocyte recirculation and apoptosis. J Leukoc Biol. 2007;81(6):1504-11. https://doi.org/10.1189/jlb.1106711.

10. Tecchio C, Micheletti A, Cassatella MA. Neutrophil-derived cytokines: facts beyond expression. Front Immunol. 2014;5:508. https://doi.org/10.3389/fimmu.2014.00508.

11. Wang H, Zhang Y, Mo P, Liu J, Wang H, Wang F, et al. Neutrophil to CD4+ lymphocyte ratio as a potential biomarker in predicting virus negative conversion time in COVID- 19 . Int Immunopharmacol. 2020; https://doi.org/10.1016/j. intimp.2020.106683.

12. Wang KX, Denhardt DT. Osteopontin: role in immune regulation and stress responses. Cytokine Growth Factor Rev. 2008;19(5-6):333-45. https://doi.org/10.1016/j. cytogfr.2008.08.001.

13. Paces J, Strizova Z, Smrz D, Cerny J. COVID-19 and the immune system. Physiol Res. 2020;69(3):379-88. https:// doi.org/10.33549/physiolres.934492.

14. YangL, LiuS, LiuJ,ZhangZ, WanX, HuangB, etal. COVID-19: immunopathogenesis and Immunotherapeutics. Signal
Transduct Target Ther. 2020;5(1):128-125. https://doi.org/ 10.1038/s41392-020-00243-2.

15. Thevarajan I, Nguyen THO, Koutsakos M, Druce J, Caly L, van de Sandt CE, et al. Breadth of concomitant immune responses prior to patient recovery: a case report of nonsevere COVID-19. Nat Med. 2020;26(4):453-5. https://doi. org/10.1038/s41591-020-0819-2.

16. Zhang B, Zhou X, Zhu C, Song Y, Feng F, Qiu Y, et al. Immune phenotyping based on the neutrophil-to-lymphocyte ratio and IgG level predicts disease severity and outcome for patients with COVID-19. Front Mol Biosci. 2020;7:157. https://doi.org/10.3389/fmolb.2020.00157.

17. Zhao J, Yuan Q, Wang H, Liu W, Liao X, Su Y, et al. Antibody responses to SARS-CoV-2 in patients of novel coronavirus disease 2019. Clin Infect Dis. 2020; https://doi.org/10. 1093/cid/ciaa344.

18. Long QX, Liu BZ, Deng HJ, Wu GC, Deng K, Chen YK, et al. Antibodyresponses to SARS-CoV-2 in patients with COVID19. Nat Med. 2020;26(6):845-8. https://doi.org/10.1038/ s41591-020-0897-1.

19. Mishima R, Takeshima F, Sawai T, Ohba K, Ohnita K, Isomoto $\mathrm{H}$, et al. High plasma osteopontin levels in patients with inflammatory bowel disease. J Clin Gastroenterol. 2007;41:167-72.https://doi.org/10.1097/MCG. 0b013e31802d6268.

20. Cantor H. The role of Eta-1/osteopontin in the pathogenesis of immunological disorders. Ann N Y Acad Sci. 1995;760:143-50. https://doi.org/10.1111/j.17496632.1995.tb44626.x.

21. Konno S, Kurokawa M, Uede T. Role of osteopontin, a multifunctional protein, in allergy and asthma. Clin Exp Allergy. 2011;41:1360-6. https://doi.org/10.1111/j.13652222.2011.03775.x

22. Chang IC, Chiang TI, Yeh KT, Lee H, Cheng YW. Increased serum osteopontin is a risk factor for osteoporosis in menopausal women. Osteoporos Int. 2010;21(8):1401-9. https://doi.org/10.1007/s00198-009-1107-7.

Publisher's Note Springer Nature remains neutral with regard to jurisdictional claims in published maps and institutional affiliations. 